\title{
Обработка холодом в технологии стабилизации вин и пути оптимизации энергозатрат
}

Антон Владимирович Сильвестров ${ }^{1}$, канд. техн. наук, заведующий лабораторией технологического оборудования и механизации сельского хозяйства, asilvestr12@mail.ru, (3654) 23-05-90;

Наталья Борисовна Чаплыгина ${ }^{1}$, науч. сотр. лаборатории технологического оборудования и механизации сельского хозяйства, aurum.22@mail.ru;

Татьяна Ивановна Ведерникова ${ }^{1}$, инженер лаборатории технологического оборудования и механизации сельского хозяйства, vinograd427@mail.ru;

Валентин Васильевич Рыжков ${ }^{1}$, инженер лаборатории технологического оборудования и механизации сельского хозяйства;

Константин Федорович Феодосиди², главный инженер-винодел, kfeodosidi@mail.ru

${ }^{1}$ Federal State Budget Scientific Institution All-Russian National Research Institute of Viticulture and Winemaking Magarach of RAS, 31 Kirova Street, 298600 Yalta, Republic of Crimea, Russia

${ }^{2} 000$ «Завод марочных вин «Коктебель», Республика Крым, пгт. Коктебель, ул. Юнге, 1

Проведен развернутый анализ существующих аппаратарно-технологических схем обработки виноматериалов холодом. Выделены проблемные места технологии обработки холодом, обоснованы пути оптимизации этого процесса. Выявлено преимущество систем непосредственного охлаждения виноматериалов. Изучены теплотехнические характеристики материалов изоляционных конструкций изотермическ их резервуаров. Установлены значимые показатели, определяющие эффективность изо ляционных конструкций. Проведен детальный анализ теплоизоляционных свойств различных материалов, применяемых для термоизоляции резервуаров, а также стабильности этих свойств во времени в условиях реального пр оизводства. Даны рекомендации по выбору оптимальной изоляционной конструкции изотермических резервуаров. Приводятся сопоставительные данные по затратам электроэнергии в традиционной схеме обработки ви номатериалов холодом и рекомендуемой. Делаются выводы о возможности сокращения и оптимизации энергозатрат на процесс обработки виноматериалов холодом. Ключевые слова: стабильность; обработка виноматериалов холодом; аппаратурно-технологическая схема; оборудование для производства холода; изоляционные материалы; изоляционная конструкция; изотермические резервуары; энергозатраты.

A нализ технологических процессов отечественного винодельческого производства показывает, что многие процессы обработки виноматериалов основаны на избыточных затратах эмектроэнергии, связанных с

\footnotetext{
Как цитировать эту статью:

Сильвестров А.В., Чаплыгина Н.Б., Ведерникова Сильвестров А.В., Чаплыгина Н.Б., Ведерникова
Т.И., Рыжков В.В., Феодосиди К.Ф. Обработка холодом в технологии стабилизации вин и пути оптимизации энергозатрат // «Магарач». Виноградарство и виноделие, 2019; 21 (2). С. 174-179. DOI 10.35547/IM.2019.21.2.019

How to cite this article:

Silvestrov A.V., Chaplygina N.B., Vedernikova T.I., Syzhkov V.V., Feodosidi K.F. Cold treatment in wine stabilization practices and ways to optimize energy consumption// Magarach. Viticulture and Winemaking, 2019; 21(2). - pp. 174-179. DOI 10.35547/IM.2019.21.2.019

удК 663.252.31/.255.9

Поступила 14.05.2019

Принята к публикации 16.05.2019

(С)Авторы, 2019
}

O R I G I N A L A R T I C L E

\section{Cold treatment in wine stabilization practices and ways to optimize energy consumption}

Anton Vladimirovich Silvestrov ${ }^{1}$, Natalya Borisovna Chaplygina ${ }^{1}$, Tatyana Ivanovna Vedernikova ${ }^{1}$, Valentin Vasilyevich Ryzhkov ${ }^{1}$, Konstantin Fedorovich Feodosidi ${ }^{2}$

${ }^{1}$ Federal State Budget Scientific Institution All-Russian National Research Institute of Viticulture and Winemaking Magarach of RAS, 31 Kirova Street, 298600 Yalta, Republic of Crimea, Russia

2Vintage Winery Koktebel" LTD, 1 Yunge Str., Koktebel, Republic of Crimea

A detailed analysis of the existing machine and technological schemes for base wine cold processing was conducted. Problem areas of cold processing technology were identified; ways to optimize this process were established. The advantages of base wine direct cooling systems were revealed. Thermo-technical characteristics of insulating structure materials used in isothermal tanks were studied. Significant indicators that determine the effectiveness of the insulating structures were established. The thermal insulation properties of various materials used for thermal insulation of the tanks undergone in-depth analysis, along with stability of these properties over time under actual production conditions. Recommendations are given as to the choice of the optimal insulating design of the isothermal tanks. Comparative data on electricity consumption using the traditional base wine cold processing scheme and the recommended one is given. Conclusions are drawn about the ways to reduce and optimize energy consumption during base wine cold processing.

Key words: stability; base wine cold processing; machine and technological scheme; equipment for the production of cold; insulating materials; insulating structure; isothermal tanks; power consumption.

необходимостью достижения розАивостойкости и типичности готовой продукции. В том числе в полной мере это относится и к закАючительному технологическому этапу приготовцения вина - его обработке с целью предотвращения образования в нем кристац-

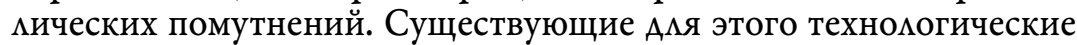
приемы, основанные на использовании холода, различных физических и химических методов стабилизации вина, а также наличие на всех винодельческих предприятиях холодильных установок и тепцообменного оборудования свидетельствуют о большом техноцогическом и экономическом значении, которое придается решению Аанной проблемы [1-11].

А^я предупреждения кристамлических помутнений вин преАцожены различные способы обработки виноматериалов, основанные на ингибировании процесса кристамлизации виннокислых сомей или повышении их растворимости. Это и обработка метавинной и мимонной кислотами, гексаметафосфатом, гуммиарабиком, тримоном Б, натрий карбоксиметилцемлюлозой и Ар. $[4,6,8,12]$.

ОАнако известно, что эффективность применения этих веществ зависит от условий хранения вина, в том числе температуры, типа вина, его физико-химического состава и Ар. Кроме того их исполь- 
зование может привести к появцению посторонних тонов во вкусе и аромате обработанных вин, нарушению их гигиеничности.

Аля частичного уАаления виннокислых солей с цемью стабимизации вина против кристаццических помутнений преАлагается испомьзовать установки, использующие ионообменные смолы, ультразвук, обратный осмос, гиперфимьтрацию, эмектродиализ [12, 13].

ОАнако применение ионообменных смол в отечественном виноделии не разрешено в связи с опасностью обогащения вин токсичными мономерами [13]. Кроме того, ионообменные смолы оказывают отрицательное влияние на органомептические показатели обработанных вин. Применение электродиализа, обратного осмоса, гиперфильтрации связано со значительными материацьными и энергетическими затратами и приводит к снижению органолептической оценки вина.

Многочисленные исследования [2, $3,5,6,11,13-16]$ и практический опыт показывают, что технологически наиболее приемлемым Аля стабимизации вин против кристацмических помутнений явцяется способ обработки виноматериалов холодом. Этот технологический прием носит универсацьный

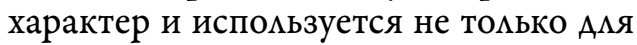
устранения избыточного содержания сомей винной кислоты, вызывающих

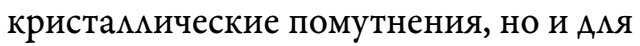
устранения также комцоидных помутнений вин. Обработка холодом способствует гармонизации и смягчению вкуса виноматериалов, интенсифицирует в них процессы, протекающие при Алительной выдержке в естественных условиях. Поэтому многие машиностроительные фирмы уделяют внимание разработке технологического оборудования Аця осуществцения Аанного процесса [17-21].

ОАнако из всех технологических обработок, которым подвергается виноматериац, обработка хомодом явцяется оАной из самых Аорогостоящих. По утвержАению Хаубса [22] энергозатраты на процесс охлаждения в виноАемии составцяют Ао $60 \%$ общих расходов преАприятия на электроэнергию.

В связи с этим актуацьной явцяется задача обеспечения необходимой стабимьности винодемьческой продукции с минимацьными энергетическими затратами.
Целью настоящей работы явцялось опредемение технико-техномогических факторов, влияющих на процесс обработки виноматериацов холодом с цемью минимизации энергозатрат.

Объекты исследования: аппаратурно-технологические схемы обработки виноматериалов холодом, применяемое технологическое оборудование, материалы изоляционных конструкций и их технико-экспиуатационные показатеми.

Очевидно, что технологическое и экономическое влияние на процесс стабимизации вин холодом оказывают технология проведения Аанного процесса и машинно-аппаратурная оснащенность производства.

Традиционно технологическая схема процесса, применяемая практически на многих винодельческих преАприятиях, выглядит следующим образом (рис.1): виноматериац из накопительного резервуара насосом прокачивается через теплообменный аппарат, охлажАаемый хиадоносителем, поступающим из машинного отАе-

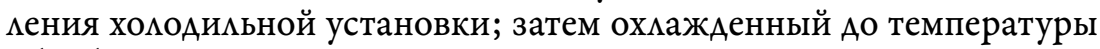
обработки виноматериал поступает в изотермические резервуары, зачастую помещенные в холодимьные камеры и снабженные Аля поААержания низкой температуры виноматериама рубашками ими змеевиками, по которым циркулирует хладоноситель.

В изотермических резервуарах виноматериал находится до 5-6 суток и более, в течение которых происходит постепенная кристалАизация винного камня и выпадение его в осадок; при этом чрезвычайно важно подАержание в течение всего времени выдержки первоначацьной низкой температуры, которая достигается, как правило, за счет хладоносителя, циркулирующего в рубашках или змеевике изотермического резервуара. При этом температура хцаАоноситемя не Аолжна быть ниже температуры охиажденного виноматериала, т.к. в противном случае образуется нацеАь из виноматериаца на стенках изотермического резервуара, т.е. вымораживание воды, поэтому

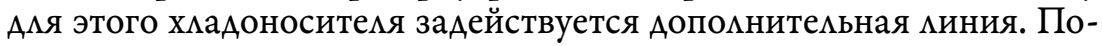
сле выдержки виноматериац насосом направцяется на фимьтрацию, а затем на следующую обработку (рис.1).

Аанная технология обработки виноматериалов холодом требует значитемьных капитацьных и текущих затрат, связанных с необходимостью применения парка изотермических резервуаров с рубашками охлаждения, специацьных холодильных камер, значительными энергозатратами, а также необходимостью в хомодиць-
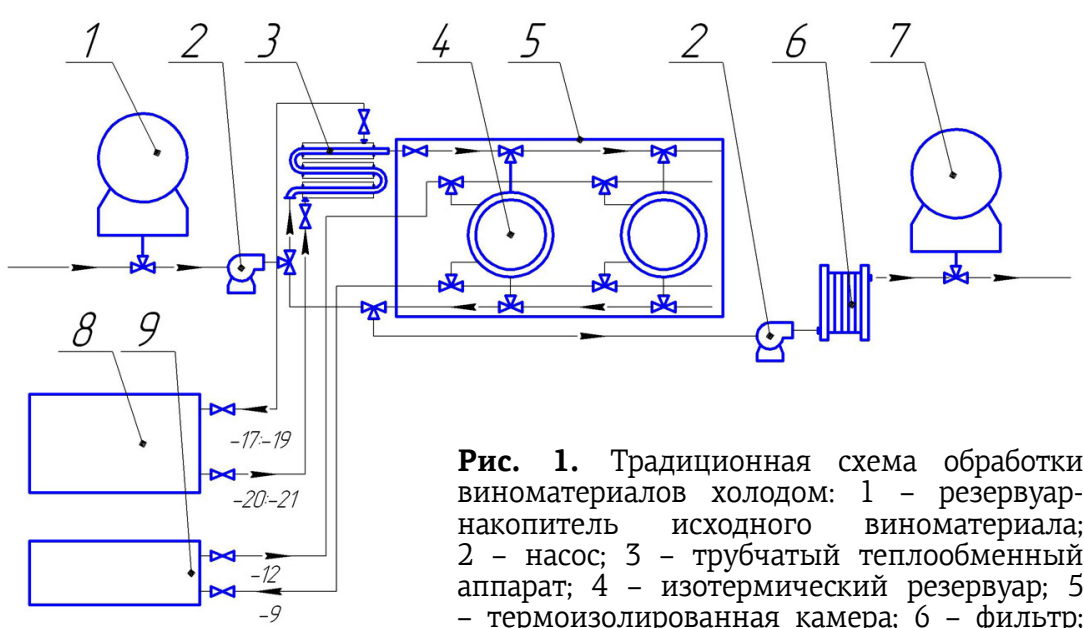

Рис. 1. Традиционная схема обработки виноматериалов холодом: 1 - резервуарнакопитель исходного виноматериала; 2 - насос; 3 - трубчатый теплообменный аппарат; 4 - изотермический резервуар; 5 - термоизолированная камера; 6 - фильтр; 7 - резервуар-накопитель; 8 - холодильная машина для хладоносителя на охлаждение виноматериала; 9 - холодильная машина для хладоносителя поступающего в рубашку охлаждения.

Fig. 1. The traditional base wine cold processing scheme: 1 - accumulation tank for untreated base wine; 2- pump; 3 - tubular heat exchanger; 4- isothermal tank; 5 - thermally insulated chamber; 6 - filter; 7 - storage tank; 8 - cold producing unit for the cooling agent for base wine cooling; 9 - cold producing unit for the cooling agent entering the cooling jacket. 
Cold treatment in wine stabilization practices and ways to optimize energy consumption

ных установках достаточной мощности. В случае использования рубашек охлаждения - специальная холодильная машина Аля подАержания необходимой температуры охлажАения виноматериала при выдержки на холоде. Особенность подобного способа обработки холодом закмючается в использовании промежуточного хмадоносителя. ХАадоноситель охлажАается в холодильной машине за счет кипения холодимьного агента. Затем хиадоносителем в тепцообменных аппаратах, как правило, трубчатого типа, охлаждается до температуры обработки виноматериал.

Расход электроэнергии при использовании промежуточного хладоносителя на $20 \%$ выше, чем в системах непосреАственного охлаждения [23]. Кроме того, используемые теплообменные аппараты трубчатого типа обладают коэффициентом теплопереда-

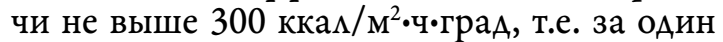
проход через теплообменник виноматериал может охладиться максимум на $15^{\circ} \mathrm{C}$. При охмаждении виноматериала от начацьной температуры $+18 \div 20^{\circ} \mathrm{C}$ этого перепада неАостаточно Аля выхода на технологические режимы минус $3 \div 5^{\circ} \mathrm{C}$ Аля столовых виноматериалов и минус $8 \div 9^{\circ} \mathrm{C}$ Аля крепленых. Поэтому виноматериал несколько раз прокачивают через теплообменный аппарат ААя Аостижения необходимой температуры охлаждения, что приводит к повышенным энергозатратам. В таком случае эффективнее испо цьзовать Аля охлаждения виноматериала в области положительных температур $\left(\right.$ Ао $\left.+2^{\circ} \mathrm{C}\right)$ пластинчатый тепкообменный аппарат с коэффициентом теплопередачи 1500 ккац $/$ ч м $^{2}{ }^{\circ} \mathrm{C}$, а затем дополнительно охлажАать виноматериац на трубчатом теплообменном аппарате. В этом случае виноматериал охлаждается за один проход через теплообменник.

Аостоинством способа непосредственного охлаждения виноматериала явцяется простота холодильной установки (рис. 2). Отсутствие промежуточного хцадоносителя Аает возможность Аця получения оАних и тех же температур обрабатываемого продукта работать холодимьной машине при более высоких температурах кипения холодицьного агента. Поэтому установка работает более экономично. В связи с этим снижаются стоимость холодицьного оборуАования и расход эмектроэнергии. Общие экспиуатационные расходы, отнесенные к 1000 ккаА/ч холодопроизводительности, снижаются на $30 \div 40 \%$.

Также эффективным способом снижения текущих производственных затрат и сбережения энергоресурсов предприятия явцяется использование изотермических

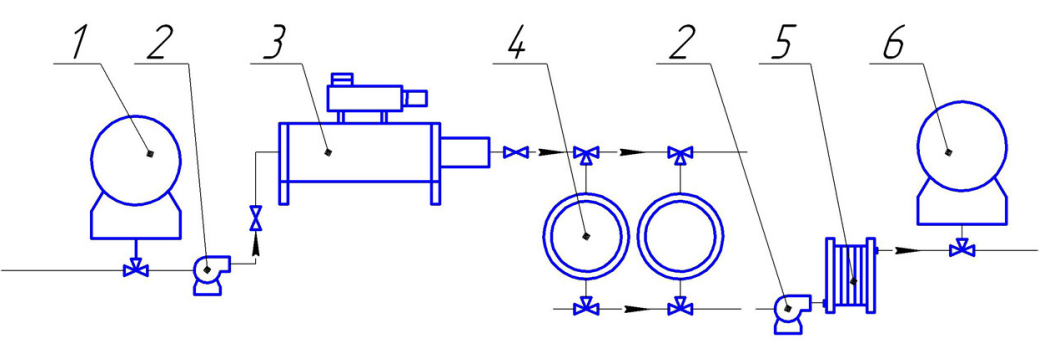

Рис. 2. Рекомендуемая схема поточной линии обработки виноматериалов холодом: 1 - резервуар-накопитель исходного виноматериала; 2 - насос; 3 - установка непосредственного охлаждения вина; 4 - изотермический резервуар (кристаллизатор); 5 - фильтр; 6 - резервуар-накопитель обработанного виноматериала

Fig. 2. The recommended scheme for the conveyer of base wine cold processing: 1 - accumulation tank for untreated base wine; 2 - pump; 3 installation for direct wine cooling; 4 - isothermal tank (cristallyzing tank); 5 - filter; 6 - accumulation tank for cold processed base wine

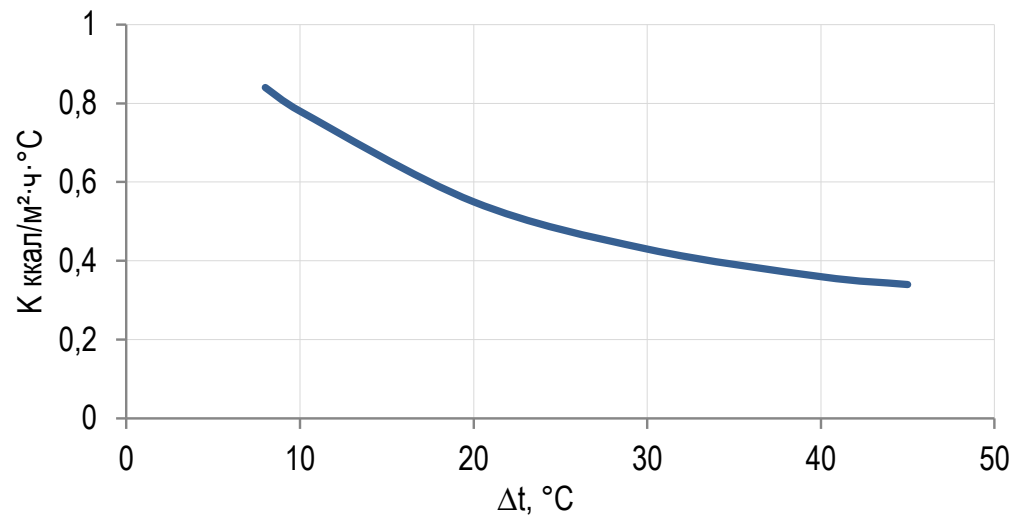

Рис. 3. Практическое значение коэффициента теплопередачи изоляционной конструкции в зависимости от разности температур окружающей среды и температуры обработки виноматериала

Fig. 3. The practical value of the insulating structure heat transfer coefficient depending on the difference of ambient temperatures and the temperature of base wine processing

резервуаров с высококачественной изоляцией, минимизирующей теплопритоки к охлажденному виноматериалу и обеспечивающей заданную температуру виноматериала в течение всего периода его выдержки на холоде. От материала изомяции, её конструкции напрямую зависит экономичность работы холоАильной машины.

Известно, что качество изоляции изотермического резервуара определяется коэффициентом теплопередачи. Коэффициент тепцопередачи рассчитывается с учетом искиючения возможности конденсации влаги на поверхности изотермического резервуара с учетом того, что температура окружающей среАы, как правимо, выше $0^{\circ} \mathrm{C}$ по формуле [24]:

$$
\mathrm{K} \leq 0,95 \alpha \frac{\mathrm{t}_{\mathrm{oc}}-\mathrm{t}^{\prime \prime}}{\mathrm{t}_{\mathrm{oc}}-\mathrm{t}_{\mathrm{B}}},
$$

где $\alpha$ - коэффициент теплопередачи от окружающей среды поверхности изотермического резервуара; $t_{o c}, t_{B}-$ температура окружающей среды и виноматериала в изотермическом резервуаре; $t^{\prime \prime}$ - температура, соответствующая точке росы в зависимости от вАажности воздуха окружающей среды.

В нашем скучае при разности температур окружающей среАы и обрабатываемого виноматериала $20 \div 30^{\circ} \mathrm{C}$ оптимальный коэффициент теплопередачи не более 0,50 ккам $/ \mathrm{m}^{2} \cdot$ ч. ${ }^{\circ} \mathrm{C}$; так как при большем значении коэффициента теплопередачи на поверхности изотермического резервуара образуется конденсат. С учетом того, что кажАый килограмм водяного пара, конденси- 
руясь на поверхности изотермического резервуара, выдемяет около 2500 кАж тепла [25], то Аля подАержания требуемого температурного режима потребуются Аополнительные энергозатраты на компенсацию теплопритоков. Кроме того коэффициент теплопередачи изоляции изотермических резервуаров напрямую зависит от коэффициента тепцопроводности изоцяционного материала.

Сравнительный анализ техникоэкономической эффективности при использовании изоляционных материалов, применяемых в винодельческой промышиенности, привеАен в табц. 1 [26].

Анацизируя теплоизоляционную эффективность преАлагаемых изомяционных материалов, необходимо отметить следующее: такие материацы, как минерацьная вата и пенопласт не ПоАХоАят ААя использования в виноде$\Lambda$ ии в связи с небольшим эффективным сроком службы и неустойчивостью к вцаге и агрессивным средам. Материал изомиат производства ООО «Специацьные технологии», по нашим исслеАованиям, проведенным на ГУП РК ПАО «Массандра», не отвечает заявменным теплотехническим характеристикам: коэффициент теплопроводности на порядок превышает значения, указанные в технической характеристике. Получивший широкое распространение в связи с монтажной техно-

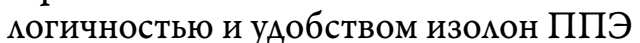
ИРА [27], преАстав Аяющий собой $\Lambda$ истовой материа размером 1000 х 2000 мм толщиной 30 мм, за время эксплуатации с 2007 г. на ПАО «Массандра» также значительно утратил свои изоляционные свойства: среАнесуточное повышение температуры виноматериала в изотермическом резервуаре объемом $14 \mathrm{M}^{3}$ с толщиной изоляции 150 мм при начацьной температуре обрабатываемого холодом виноматериала минус $6,5^{\circ} \mathrm{C}$ на сегодняшний Аень составимо $0,4^{\circ} \mathrm{C}$, что выше первоначамьной $0,3^{\circ} \mathrm{C}$. На поверхности этого резервуара появицся конденсат, которого не бымо изначацьно, выросло значение коэффициента теплопередачи на 40 \%. Мы считаем, что причиной ухудшения теплотехнических свойств Аанного изомяционного материала явимось нарушение техноцогии изготовцения при вспенивании. Попавший в полости при вспенивании возАух содержит вцагу, которая, конденсируясь, пропиты-
Таблица 1. Сравнительный анализ технико-экономической эффективности при использовании изоляционных материалов

Table 1. Comparative analysis of technical and cost effectiveness when using insulation materials

\begin{tabular}{|c|c|c|c|c|c|}
\hline Показатеми & $\begin{array}{l}\text { Пенопо- } \\
\text { миуретан } \\
\text { ППу }\end{array}$ & $\begin{array}{l}\text { Мине- } \\
\text { рацьная } \\
\text { вата }\end{array}$ & $\begin{array}{l}\text { Пено- } \\
\text { пласт } \\
\text { ПХВ-1 }\end{array}$ & $\begin{array}{l}\text { Изолон } \\
\text { ППЭ ИРА } \\
30 / 30\end{array}$ & $\begin{array}{l}\text { Изо - } \\
\text { цат }\end{array}$ \\
\hline
\end{tabular}

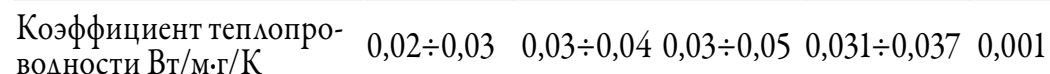
воАности Вт/м·г/К Аиапазон рабочих темпе- $-100 \ldots+180 \quad-40 \ldots+120 \quad-50 \ldots+110 \quad-50 \ldots+150 \quad-50 \ldots+150$ ратур ${ }^{\circ} \mathrm{C}$

Степень плотности, кг $/ \mathrm{m}^{3} 40 \div 200$

$55-150 \quad 30-60 \quad 33-200$
300

Эффективный срок службы, $л е т$

$25 \div 30 \quad 5 \quad 5 \div 8 \quad 15 \div 20$
$15 \div 20$

Устойчивость к вцаге и агрессивным средам

устойчив

тепцоизомяционные свойства теряются

устойчив

устойчив

Таблица 2. Сопоставительные данные по затратам электроэнергии при традиционной схеме обработки виноматериалов холодом и рекомендуемой схеме

Table 2. Comparative data on electricity consumption in the traditional base wine cold processing scheme and the recommended one

\begin{tabular}{|c|c|c|}
\hline \multirow[b]{2}{*}{ Наименование показатемей } & \multicolumn{2}{|c|}{ Значение показатемя } \\
\hline & $\begin{array}{l}\text { традицион- } \\
\text { ная схема }\end{array}$ & $\begin{array}{l}\text { рекомендуе- } \\
\text { мая схема }\end{array}$ \\
\hline $\begin{array}{l}\text { УАельный расхоА электроэнергии на охлажАение вино- } \\
\text { материала, } к \mathrm{BT} / 1000 \text { Аа }\end{array}$ & 151,4 & 151,4 \\
\hline 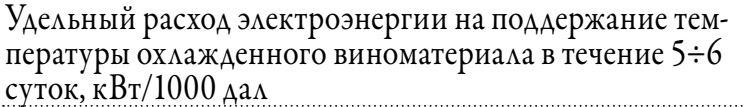 & $79,2 \div 95,0$ & - \\
\hline
\end{tabular}

вает изоляционный материал, снижая его изоляционные свойства. Анализируя полученные резумьтаты, необходимо отметить, что наицучшими экспиуатационными свойствами по многоцетним набцюАениям обладает изоцяция из пенополиуретана. Этот материа при собцюдении технологии изготов ения изоцяционного покрытия сохраняет свои изоляционные свойства без изменения в течение срока Алитемьной эксплуатации. Изотермические резервуары, изготовленные с изоляционным покрытием из пенополиуретана толщиной не менее 200 мм, при перепаде температур внешней среды и выдерживаемого на холоде виноматериала до $\mathrm{t}=30^{\circ} \mathrm{C}$ не нужАаются в Аопо нительном охлаждении с помощью рубашек ими змеевиков, что также позвоцяет экономить энергозатраты на Аанный техноцогический процесс.

Кроме того, эффективность обработки виноматериалов холодом зависит от подготовки виноматериаца к обработке, его физико-химического состава, температуры. Поэтому общепризнаны рекоменАации по частичному преАварительному удацению из него веществ коммоидной природы путем воздействия на виноматериал физическими, химическими ици биохимическими способами обработки, что позвоцяет сократить время выдержки виноматериалов на холоде при достижении максимацьного технологического эффекта.

Сопоставитемьные Аанные по затратам эмектроэнергии в традиционной схеме обработки виноматериалов хомодом и рекомендуемой с цемью сокращения энергозатрат (табц. 2).

Выводы. Изучение аппаратурно-технологических схем и оборудования Аця обработки виноматериалов холодом позвоцимо выявить преимущество систем непосреАственного охлажАения, позвоцяющих искмючить промежуточный хмадоноситемь и сэкономить энер- 
гозатраты на $20 \%$.

Исследование эффективности изоцяционных конструкций позволимо определить оптимацьный коэффициент теп опередачи не более 0,50 кка $/ \mathrm{M}^{2} \cdot{ }^{\circ}{ }^{\circ} \mathrm{C}$.

Аетацьный анациз тепцоизомяционных свойств разцичных конструкционных материалов, применяемых Аля термоизомяции резервуаров, а также стабимьности этих свойств во времени в условиях реацьного производства показывает, что наиболее приемлемой яв яется тепцоизоцяция пенопомиуретаном ППУ толщиной не менее 200 мм.

Применение технологии непосреАственного охмаждения виноматериалов с использованием изотермических резервуаров или кристациизаторов, изоляционная конструкция которых обеспечивает суточное падение температуры обрабатываемого виноматериа$\Lambda$ не более $0,1 \div 0,2^{\circ} \mathrm{C}$, по сравнению с традиционной технологией обработки виноматериалов холодом позвоцяет экономить Ао 60\% затрат электроэнергии на 1000 Аац обрабатываемого виноматериа а.

\section{Источник финансирования}

Не указан.

\section{Financing source}

Not specified.

\section{Конфликт интересов}

\section{Не заявмен.}

\section{Conflict of interests} Not declared.

\section{Список литературы / References}

1. Сборник основных правил, технологических инструкций и нормативных материалов по производству винодельческой продукции. Под ред. Саришвили Н.Г. М.: Пищепромиздат, 1998. 244 с.

Sbornik osnounyh pravil, tekbnologicheskih instrukcij i normativnyh materialov po proizvodstvu vinodel'cheskoj produkcii. Ed. by Sarishvili N.G. Moskva: Pishchepromizdat, 1998. 244 p. (in Russian)

2. Рибейро-Гайон Ж., Пейно Э и др. Теория и практика виноделия, М: Легкая и пищевая промышленность. Т.4, 1981. 416 с.

Ribejro-Gajon ZH., Pejno E i dr. Teoriya $i$ praktika vinodeliya [Theory and Practice of Winemaking], M: Legkaya $i$ pishchevaya promyshlennost'. Vol.4, 1981. 416 p. (in Russian)

3. Кишковский 3.Н. Современные способы стабилизации вин / Материалы международного симпозиума по технологии виноделия 20-25 августа 1979 г. Кишинев: Штиинца. С. 118-134.

Kishkovskij Z.N. Sovremennye sposoby stabilizacii vin [Contemporary wine stabilization methods]/ Materialy mezhdunarodnogo simpoziuma po tekbnologii vinodeliva 20-25 avgusta 1979 g. Kishinev: Shtiinca. pp. 118-134. (in Russian)

4. Кишковский 3.Н., Мержаниан А.А. Технология вина. М: Легкая и пищевая промышленность. 1984. 504 с.

Kishkovskij Z.N., Merzhanian A.A. Tekhnologiya vina [Wine production technology]. M: Legkaya i pishchevaya promyshlennost'. 1984. 504 p. (in Russian)

5. Валуйко Г.Г., Зинченко В.И., Мехузла Н.А. Стабилизация виноградных вин. М.: Агропромиздат. 1987. 159 с.

Valujko G.G., Zinchenko V.I., Mekhuzla N.A. Stabilizaciya vinogradnyb vin. [Stabilization of Grape Wines]. Moskva: Agropromizdat. 1987. 159 p. (in Russian)

6. Агеева Н.М. Научно-практические рекомендации по вопросам стабилизации вина, Краснодар. 1999. 54 с.

Ageeva N.M. Nauchno-prakticheskie rekomendacii po voprosam stabilizacii vina [Scientific and practical recommendations on wine stabilization], Krasnodar. 1999. 54 p. (in Russian)

7. Якименко О.В., Осадчий А.В., Чаплыгина Н.Б., Виноградов В.А. и др. Новая установка для ускоренной стабилизации вин против кристаллических помутнений ВУС-2,5 // «Магарач». Виноградарство и виноделие. 2003. № 4. С. 23-27.
Yakimenko O.V., Osadchij A.V., Chaplygina N.B., Vinogradov V.A et al. Novaya ustanovka dlya uskorennoj stabilizacii vin protiv kristallicheskih pomutnenij VUS-2,5 [A new installation for accelerated stabilization of wines against crystallic haze BYG-2,5] // "Magarach». Vinogradarstvo i vinodelie. [Magarach. Viticulture and Winemaking]. 2003. № 4. pp. 23-27. (in Russian)

8. Шольц-Куликов Е.П. Виноделие по-новому. Симферополь: Таврида. 2009.320 c.

Shol'c-Kulikov E.P. Vinodelie po-novomu. Simferopol': Tavrida. 2009. 320 p. (in Russian)

9. Виноградов В.А., Чаплыгина Н.Б., Кулёв С.В. Практическое решение проблемы стабилизации виноматериалов холодом // ВиноГрад. 2010. № 9. С. 66-69.

Vinogradov V.A., Chaplygina N.B., Kulyov S.V. Prakticheskoe reshenie problemy stabilizacii vinomaterialov bolodom [The practical solution to the problem of base wine stabilization with cold]// VinoGrad. 2010 № 9. pp. 66-69. (in Russian)

10. Виноградов В.А., Кулёв С.В., Чаплыгина Н.Б. Новое технологическое оборудование для виноделия / ВиноГрад. 2012. № 6. С. 38-49.

Vinogradov V.A., Kulyov S.V., Chaplygina N.B. Novoe tekbnologicheskoe oborudovanie dlya vinodeliva [The new technological machinery for winemaking] / VinoGrad. 2012. № 6. pp. 38-49. (in Russian)

11. Виноградов В.А., Загоруйко В.А., Кулёв С.В., Чаплыгина Н.Б. Оборудование для комплексной обработки виноматериалов против коллоидных и кристаллических помутнений / Виноградарство и виноделие. Сборник научных трудов НИВиВ «Магарач». Т. 44 C. 86-92.

Vinogradov V.A., Zagorujko V.A., Kulyov S.V., Chaplygina N.B. Oborudovanie dlya kompleksnoj obrabotki vinomaterialov protiv kolloidnyb ikristallicheskib pomutnenij/Vinogradarstvo i vinodelie. Sbornik nauchnyh trudov NIViV «Magarach». Vol. 44. pp. 86-92. (in Russian)

12. Таран Н.Г., Зинченко В.И. Современные технологии стабилизации вин, Кишинев. 2006. 240 с.

Taran N.G., Zinchenko V.I. Sovremennye tekhnologii stabilizacii vin, Kishinev. 2006. 240 p.

13. Исламов М.Н. Использование процесса электродиализа в винодельческом производстве //Виноделие и виноградарство. 2007. №5. C.26-27.

Islamov M.N. Ispol'zovanie processa elektrodializa v vinodel'cheskom proizvodstve //Vinodelie $i$ vinogradarstvo. 2007. №5. pp.26-27. (in Russian)

14. Виноградов В.А., Загоруйко В.А., Кулёв С.В., Чаплыгина Н.Б. и др. Исследование технологического процесса комплексной стабилизации виноматериалов против коллоидных и кристаллических помутнений / Виноградарство и виноделие. Сб. научн.тр. НИВиВ «Магарач». T. 43. C. 83-88.

Vinogradov V.A., Zagorujko V.A., Kulyov S.V., Chaplygina N.B. i dr. Issledovanie tekbnologicheskogo processa kompleksnoj stabilizacii vinomaterialov protiv kolloidnyb $i$ kristallicheskih pomutnenij /I Vinogradarstvo $i$ vinodelie. [Collection of scientific papers of the Institute Magarach]. Vol. 43. pp. 83-88. (in Russian)

15. Виноградов В.А., Кулёв С.В., Чаплыгина Н.Б. Стабилизация виноматериалов против кристаллических помутнений во взвешенном слое осадка // «Магарач». Виноградарство и виноделие. 2014. № 4. C. 31-33.

VinogradovV.A., Kulyov S.V., Chaplygina N.B. Stabilizaciva vinomaterialov protiv kristallicheskib pomutnenij vo vzveshennom sloe osadka [Base wine stabilization against crystal haze in the suspended laver of the sediment]/ «Magarach". Vinogradarstvo $i$ vinodelie. [Magarach. Viticulture and Winemaking]. 2014. № 4. pp. 31-33. (in Russian)

16. Виноградов В.А., Авидзба А.М., Загоруйко В.А., Чаплыгина Н.Б. и др. Сокращение энергозатрат на производство «холода» в условиях НПАО «Массандра» // Виноградарство и виноделие. Сб. научн. тр.НИВиВ «Магарач». Т. 38. С. 121-124.

Vinogradov V.A., Avidzba A.M., Zagorujko V.A., Chaplygina N.B. i dr. Sokrashchenie energozatrat na proizvodstvo "boloda" v usloviyah NPAO "Massandra" // Vinogradarstvo $i$ vinodelie. Collection of scientific papers of the Institute Magarach. Vol. 38. pp. 121-124. (in Russian) 
17. «Refrigeratore con s cambiatore tubo in tubo» проспект фирмы Vilo Италия. 2009. 2 p.

18. «Enonefrigeratori» проспект фирмы Della Toffola S.P.A., Италия. $2013.6 \mathrm{p}$.

19. «Cooling Systems» проспект фирмы Spadoni, Италия. 2016. 8 р.

20. «Equipment for the winery» проспект фирмы РІМ Болгария. 2012. $28 \mathrm{p}$.

21. «Refrigeratori» проспект фирмы ТMCI Padovan Spa, Италия. 2010. 4 p.

22. Kolher.N, Miltenberger R, Kristallbildurg in Wein / Bayer Landwirt. 1981. № 3. S 55-69.

23. Ильин Е.В., Мальгина Е.В. Холодильные машины и установки. Москва: Государственное издательство торговой литературы, 1960. $400 \mathrm{c}$.

Il'in E.V., Mal'gina E.V. Holodil'nye mashiny $i$ ustanovki. Moskva: Gosudarstvennoe izdatel'stvo torgovoj literatury, 1960. 400 p. (in Russian)

24. Комаров Н.С. Справочник холодильщика. Москва: Государственное научно-техническое издательство машиностроительной литературы, 1962. 419 с.

Komarov N.S. Spravochnik bolodil'shchika [Refrigirationist's manual].
Moskva: Gosudarstvennoe nauchno-tekbnicheskoe izdatel'stvo mashinostroitel'noj literatury [State scientific and technical publisher's house of machine-building literature], 1962.419 p. (in Russian)

25. Справочник по теплообменникам: в 2-х т. Т. 2 / Пер. с англ. под ред. Мартыненко О.Г. и др. - Москва: Энергоатомиздат, 1987. 352 с.

Spravochnik po teploobmennikam: in 2 volumes, V. 2 / Translated from English under the editorship of Martynenko O.G. et al. - Moskva: Energoatomizdat, 1987.352 p. (in Russian)

26. Изоллат. Рекламный листок 000 «Специальные технологии». Сравнительный анализ технико-экономической эффективности при использовании пенополиуретана, минеральной ваты, пенопласта и изоллата. Екатеринбург: 000 «Специальные технологии». 2007. 1 с.

Izollat. Reklamnyj listok 000 Special'nye tekhnologii. Sravnitel'nyj analiz tekbniko-ekonomicheskoj effektivnosti pri ispol'zovanii penopoliuretana, mineral'noj vaty, penoplasta $i$ izollata. Ekaterinburg: OOO Special'nye tekhnologii. 2007. 1 p. (in Russian)

27. Изолон. Рекламный листок. Ижевск: АО Ижевский завод пластмacc. 2007. 3 C.

Izolon. Reklamnyj listok. Izhevsk: AO Izhevskij zavod plastmass. 2007. 3 p. (in Russian)

\section{Памяти ученого}

6 мал 2019 года ушел из жизни доктор технических наук, заслуженный изобретатель Украины, профессор кафедры биотехнологии продуктов брожения, экстрактов и напитков, декан факультета бродильных, консервных производств и экологического контроля, заместитель директора по вопросам научной и патентно-лицензионной деятельности Национального университета пищевых технологий (г. Киев) Шиян Петр Леонидович.

Шиян Петр АеониАович родићся 16 июня 1946 г. в г. Киев.

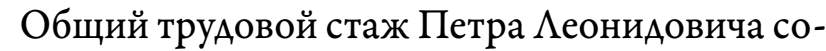
ставляет 49 Ает, 40 из которых приходится на научно-педагогическую деятельность в НУПТ.

Вся творческая, научная и педагогическая деятельность Петра Аеонидовича была посвящена совершенствованию техномогии ректификованного и технического спирта. ПоА его руковоАством были разработаны энерго- и ресурсосберегающие брагоректификационные установки, а также инновационные технологии пищевого, технического и топцивного этаноца, большинство из которых внедрены на предприятиях Украины и стран СНГ.

Профессор Шиян П.А. - мауреат Государственной премии Украины в сфере науки и техники, заслуженный изобретатель Украины, победитель Всеукраинского конкурса «Изобретатемь года», мауреат премии Кабинета министров Украины. За пмодотворную научную деятельность

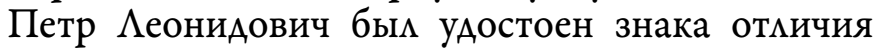
«За научные и образовательные достижения» и отмечен почетными грамотами Министерства образования и науки Украины, Кабинета министров
Украины и Верховной рады Украины.

В научную школу профессора входят ученики, которые на сегоАняшний день работают на предприятиях Украины, Словакии, Польши, Австралии, Чехии, Канады, Новой Зеланаии, России, Бемаруси, Туркменистана, АзербайАжана и Аругих стран.

Авторский вкцаА

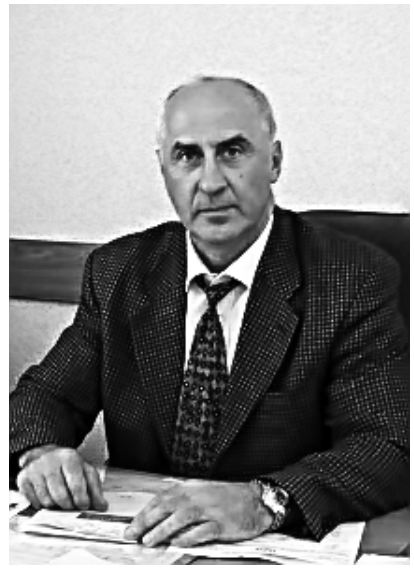

П. $\Lambda$. Шияна насчитывает свыше 150 научных статей, более 100 авторских свиАетемьств, патентов и мицензий.

Петра Аеонидовича связывака творческая и $\Lambda$ миная Аружба с сотрудниками института «Ма-

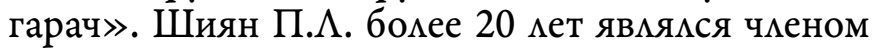
Аиссертационного совета института.

Большой профессионац своего Аела, светлый и отзывчивый человек - таким Петр Аеонидович Шиян останется в сердцах родных и близких, колмег и учеников. 